\title{
PHYTOCHEMICAL CONSTITUENTS OF THE LEAVES OF STERCULIA SETIGERA
}

\author{
HAMIDU, ABUBAKAR AHMED \\ Chemistry department, adamawa state university, mubi, adamawa state.
}

\begin{abstract}
Many countries of the world particularly Africa are abundantly blessed in terms of plants most of which exist in the wild. Some of these are consumed as leafy vegetable particularly as source food and as curative therapeutic agent for relieving pain and curing ailments. Hence the practical need for phytochemically screening these plants and proper characterisation of these sleeping giants for their utilization as precursors in pharmaceutical related applications. This systematic documented procedure could serve as useful information sources for drug related applications and facts to buttress the claims by the traditional forerunners and subsequent comparison of orthodox and traditional systems.
\end{abstract}

In this regard, Elucidation of the crude drug of STERCULIA SETIGERA, (family: STERCULIACEAE) leaves was carried out in terms of physico-chemical techniques. Phytochemcial screening showed the presence of alkaloids, flavonoids, phenolic and glycosides. The powdered plant subsequent extraction was carried out with methanol. Further analysis was carried out for quantitative determinations of sugars by TLC. The methanolic extract tested positive for all the phytoconstituents under the present investigation. TLC analysis of the methanolic extract gave three spots RF values of 0.86 for aglycone and 0.92 for flavonoidal glycoside (Glycon).Reducing and non reducing sugars were also carried out by hydrolysis. A positive test was obtained for the presence of reducing and non-reducing sugars.

Keywords: Flavonoidal glycosides, Reducing Sugar, RF values, phytochemical constituents, phytochemical screening.

\section{INTRODUCTION}

Many countries of the world, and Africa in particular are abundantly blessed with plants most of which occur in the wild. Some of these plants are well known medicinal plants with several uses attributed to them. Some of these plants are consumed as leafy vegetables while some in the traditional society reported through experience inherited from one generation to another have been reported to have a very useful activity both in traditional and pharmaceutical aspects.

Sterculia setigera is a tree or shrub of upto 40 feet high and $5 \mathrm{ft}$ width, deciduous, pale purplish bark, smooth with thin scales which peel off to expose yellowish patches.

\section{MATERIAL AND METHODS}

\section{MATERIALS}

The leaves of sterculia setigera were obtained from Dougerei, a settlement right in the heart of Yola, the Adamawa State capital.

$150 \mathrm{~g}$ of sterculia setigera leaves were dried and ultimately pulverized using an electrical crusher. The powder formed was stored in a polythene bag until needed for analysis.

\section{METHODS}

The methods of Sofowara 1978, 1993 for the presence of alkaloids, saponins, flavonoids flavones etc. was adopted for this investigations.

\section{EXTRACTION PROCEDURE}

Using the method of cold extraction as described by Sofowara( 1993).

$150 \mathrm{~g}$ of the leaves was soaked in a round bottom flask using methanol. The conical flask was sealed and kept for two days i.e. 48 hours. The soaking was to allow the flavonoidal compounds to be absorbed by the solvents.

The soaked leave samples were then well shaken and transferred to a $250 \mathrm{ml}$ beaker using filter paper. The filtrate was dried in Air oven for an hour and the recovered methanol was sequentially used for the same residue. This process was repeated at least three times. 


\section{RESULTS AND DISCUSSION}

\section{RESULTS}

TABLE .I -PHYTOCHEMICAL SCREENING OF METHANOLIC LEAVE EXTRACT

\begin{tabular}{|l|c|}
\hline CLASS OF PHYTOCOMPOUND & INFERENCE \\
\hline PHENOLICS & + \\
FLAVONE & + \\
GLYCOSIDE & + \\
SAPONIMS & + \\
PHENOLS & + \\
TANNINS & + \\
\hline
\end{tabular}

+ presence of the compounds

- Absence of the compounds

TABLE. II- REDUCING AND NON-REDUCING SUGAR

\begin{tabular}{|l|l|}
\hline SUGAR & LEAVE \\
\hline Reducing Sugar & Positive \\
Non-reducing Sugar & Positive \\
\hline
\end{tabular}

TABLE .III - THIN LAYER CHROMTOGRAPHIC CHARACTERISTICS OF STERCULIA SETIGERA (LEAVES)

\begin{tabular}{|l|l|l|c|c|}
\hline Sample & Developing System & $\begin{array}{l}\text { Visualization } \\
\text { reaction }\end{array}$ & $\begin{array}{c}\text { No. of } \\
\text { spots }\end{array}$ & RF Value \\
\hline $\begin{array}{l}\text { Methanol Extract } \\
\text { (glycoside) }\end{array}$ & $\begin{array}{l}\text { Chloroform: Ethanol: water } \\
(113.5: 1.8: 35.5)\end{array}$ & Iodine & 1 & 0.92 \\
\hline $\begin{array}{l}\text { Methanolic } \\
\text { Extract Aglycen }\end{array}$ & $\begin{array}{l}\text { Butanol: Ethanol: water } \\
(10: 3.5: 1.8)\end{array}$ & Iodine & 2 & 0.86 \\
\hline
\end{tabular}

TABLE IV - ORGANOLEPTIC CHARACTERISTICS OF THE LEAVES

\begin{tabular}{|l|l|}
\hline PARAMETERS & \\
\hline COLOUR & INFERENCE \\
\hline Texture & GREEN \\
\hline Taste & Smooth, powdery \\
\hline Odour & Bitter \\
\hline Moisture & Mild \\
\hline Ash content & $45 \%$ \\
\hline
\end{tabular}




\section{DISCUSSION}

The phytochemical screening for all the chemical constituents under consideration for this investigation showed positive results for all the phytoconstituents in the leaves of sterculia setigera which is in line with the works of (Adebajo et al,1983) whose works reported the presence of tannin, glycosides, alkaloide sapanonins and polyphenols. The is shown in Table 1.

The test carried out to ascertain the presence of reducing and non-reducing sugars tested positive for both reducing and nonreducing sugars which is in line with the work of (Safowara,1993) and this is shown in Table II.

TLC analysis for the presence of glycoside and aglycon showed positive result with RF value of 0.92 and 0.86 respectively. This is shown in Table III.

More so the active ingredients that tested positive in this investigations is in line with studies (Okolo,1987) which have shown that antimicrobial properties of vegetables and other plants are dependent on certain active substances which included glycosides, alkaloids, saponins, tannins, flavonoids and various other oils. These serve as starting materials for the synthesis for production of new drugs today.

The organoleptic characteristic of the leave is shown in Table IV. This shows that the leaves have edible properties and may be incorporated into animal feeds.

\section{CONCLUSION}

The presence of phytoconstitents goes a long way to show that the leaves of sterculia setigera have great potentials as suppliers of vital ingredients and starting materials for drug synthesis or production. However, further studies can be carried out on the antimicrobial activities and structural Elucidations by complimentary instrumental analysis such as NMR, Mass spectroscopy, so as to ascertain the active components and chemical moieties responsible for their chemical activities.

\section{REFERENCES}

1. Ajibota A. O. (2004); Essential Medicinal Chemistry Shanesen C. I. Limited Ibadan, Nigeria.

2. Adebajo A. O, Adewumi, C.O and Essein E.E. (1983). Anti-Infective agents of higher plants Symposium of Medicinal plants $5^{\text {th }}$ edition University of Ife, Nigeria Pp. 152, 158.

3. Nigerian Tress by R.W.J. Kecy, Vol. II, 200-231, (1960).

4. Odebiyi and A. E. Sofowara (1978) Phytochemical Screening of Nigerian Plants, Iloydia 4,1,3, 234-236.

5. Okolo, J. O. (1987). Strategies for Enhancement and Utilization potentials of Edible Woody Forestry species of African plants, FLJG Vander Macsen et al, Pub Kluwar, Netherlands Pp. 64-105.

6. Sofowara A. (1993) Medicinal Plants and Traditional Medicine in Africa Chichester John, Vuley and Sons, New York p. 256. 